\title{
The Role of the East Java Innovation Hub in Fostering Good Local Governance
}

By Redhi Setiadi, Elke Rapp, and Gabe Ferrazzi ${ }^{1}$

\section{Background}

Innovation in local governance and its replication are cherished goals of many proponents of local governance. Innovation solves public service problems. Replication, in whole or in part, multiplies the impact of innovation to attain system-wide changes. Local governments are taking more responsibility in achieving the Sustainable Development Goals (SDGs), particularly on basic service delivery. Innovation offers all levels of government a way to do this more effectively within resource constraints. ${ }^{3}$
Collaboration often takes the form of knowledge sharing or innovation hubs that aim to spread a culture of innovation and promote replication. Over the last 2 decades, public and private (or mixed) innovation hubs have shown that public services can be improved through sharing information and providing support to potential innovators. Problem-focused and collaborative innovation teams have been formed within national governments, with external experts and service users being enlisted. ${ }^{4}$ This approach breaks down sector and government-citizen barriers that hinder innovation. Such efforts

Redhi Setiadi (redhi.setiadi@gmail.com) is a local governance expert and has been involved in Indonesian decentralization since its inception in 2001 through monitoring and evaluation activities. He currently serves as the provincial advisor for East Java at the Transforming Administration - Strengthening Innovation (TRANSFORMASI) Bureaucracy Reform Support Program, an Indonesian-German program implemented by the Ministry of State Apparatus and Bureaucratic Reform, and the Deutsche Gesellschaft für Internationale Zusammenarbeit (GIZ) GmbH through the GFA Consulting Group. Elke Rapp (elkerapp@gmx.net) is a senior governance expert and a leading expert on Indonesian decentralization and governance. She has extensive experience in international cooperation, sustainable development, and capacity development and manages governance programs for the Asian Development Bank (ADB), GIZ, and United States Agency for International Development (USAID) in Asia. Under the GFA, she leads the TRANSFORMASI program team on behalf of GIZ in Jakarta, Indonesia. Gabe Ferrazzi (gabeferrazzi@rogers.com) is a governance specialist whose work focuses on decentralization in Asia. As an independent consultant, he has supported policy making in many countries through his work with bilateral and multilateral development partners. He is also an educator and currently an adjunct professor in the School of Environmental Design and Rural Development at the University of Guelph in Canada.

2 United Cities and Local Governments. 2017. National and Subnational Governments on the Way Toward the Localization of the SDGs. Barcelona.

3 United Nations Development Programme. 2017. Innovate. Create. Change. New Ideas that Power SDG Progress in Asia and the Pacific. New York.

4 R. Puttick, P. Baeck, and P. Colligan. 2014. i-Teams: The teams and funds making innovation happen in governments around the world. Nesta and Bloomberg Philanthropies: London. 


\section{Innovation in local}

governance and

its replication are

cherished goals of many proponents of

local governance. include the Impact and Innovation Unit (formerly Innovation Hub) in Canada's Privy Council Office, a body that directly supports the Prime Minister and Cabinet. ${ }^{5}$ The Impact and Innovation Unit seeks to translate Canada's Blueprint 2020 into world-class improvements to public services. Similar hubs can be found in other developed and developing countries. ${ }^{6}$ In South Africa, the government founded the Center for Public Service Innovation and gave it legal strength through the Public Service Act, 1994. ${ }^{7}$ The center has added value as a venue for annual public service awards for government organizations and conferences for government organizations, innovation practitioners, private sector representatives, and academics. ${ }^{8}$

Similarly, the Government of Indonesia considers innovation a core concern, from national to subnational levels. The Ministry of State Apparatus and Bureaucratic Reform (Ministry of PANRB), in its regulations of 2018 , defines innovation as a "breakthrough in public service based on an original idea or adaptation/modification that brings benefits to the people, directly or indirectly." Although not specified in the regulation, this definition includes the concept of replication (innovation with adaptation or modification). The Ministry of PANRB promotes innovations to improve frontline services in health, education, civil registry, and environmental protection. Innovation hubs have been established in the provinces of East Java, South Sulawesi, and South Sumatra through bilateral cooperation. ${ }^{10}$ Within each innovation hub, both provincial government staff and civil society (e.g., academe and media) engage regional governments, nongovernment organizations, and the private sector in building innovation capacity and spreading proven innovations that contribute toward achieving the SDGs by 2030.

The Ministry of PANRB commissioned a study that focused on the oldest innovation hub, the Public Service Innovations Network (Jaringan Inovasi Pelayanan Publik or JIPP) in East Java, to assess its impact and find evidence of how it affects the province to spur innovation in its regional (district and city) governments. ${ }^{11}$ The research was conducted in 2018. It employed qualitative methods, including semistructured interviews with key stakeholders (regional government officials and other actors involved in innovation and replication efforts) and mini case studies. This governance brief summarizes the key findings of the study.

\section{Before the Establishment of the East Java Innovation Hub}

Innovation in the districts and cities of East Java has been evident since decentralization reforms began in 2001, following the revised 1999 legal framework for regional government. Regional leadership drove innovation. Early on, the competitive approach was successful with regional governments responding to a competition organized by the Jawa Pos Institute of Pro-Autonomy. ${ }^{12}$ This featured good practices in frontline services that resulted in significant improvement of public services. Every year, the best innovations were divided into three broad categories: economic development innovations, public services, and local political performance. The three best innovations in each category received autonomy awards.

5 Government of Canada. Impact and Innovation Unit. https://www.canada.ca/en/innovation-hub.html.

6 Other countries include Chile (Gobierno Laboratory), Denmark (MindLab), Finland (Change Makers Network), France (The 27th Region), Northern Ireland (Regulatory Impact Assessments), Singapore (Human Experience Lab and Smart Nation Program Office), Sweden (Co-Labs), the United Arab Emirates (Center for Government Innovation), the United Kingdom (UK Policy Lab, What Works Network), and the United States (Presidential Innovation Fellows Program).

7 Government of South Africa. 2019. Rationalisation of Public Administration under the Constitution of the Republic of South Africa, 1993: Replacement of Laws on Public Services. Public Service Act, 1994. https://www.gov.za/documents/constitutionrepublic-south-africa-rationalisation-public-administration-replacement-laws.

8 Centre for Public Service Innovation. About Us. Arcadia. http://www.cpsi.co.za/about-us/.

9 Peraturan Menteri Pendayagunaan Aparatur Negara Dan Reformasi Birokrasi Republik Indonesia Nomor 3 Tahun 2018 Tentang Kompetisi Inovasi Pelayanan Publik Di Lingkungan Kementerian/Lembaga, Pemerintah Daerah, Badan Usaha Milik Negara, Dan Badan Usaha Milik Daerah Tahun 2018

10 The TRANSFORMASI program is a bilateral cooperation between the Government of Indonesia and the German Federal Government, with GIZ/GFA as implementing partners.

11 TRANSFORMASI - Peran Innovation Hub Dalam Menumbuhkembangan Inovasi Pelayanan Publik di Jawa Timur (The Role of Innovation Hubs in Developing Public Service Innovations in East Java) was a study that assessed the innovation environment in public service delivery in Indonesia and in particular the impact of the recently founded innovation hubs. Results of the study have been presented to international and national audiences on several occasions. The study, which served as the basis of this article, is also intended to support policy formulation for the replication of innovations.

12 The Jawa Pos Institute of Pro-Autonomy was established by the Jawa Pos Group (a media company) in 2001 to further people's welfare through effective regional autonomy. 
The annual Autonomy Awards Competition supported innovation in East Java up to 2014. A study conducted by the Jawa Pos Institute of Pro-Autonomy in the same year found 30 local governments had received 55 awards during 2004-2013. Some of the recognized innovations have continued to flourish since being introduced. But many stagnated due to the politically driven desire of the new local leadership to highlight its own breakthroughs in service delivery.

The Ministry of PANRB also became more involved in promoting innovation in regional government in 2014. It launched a national innovation competition (SINOVIK), which is very popular and attracts more than 3,000 submissions annually. An independent panel team selects innovations - from 99 down to the top 40. In 2017, SINOVIK recognized 10 provincial innovations, 3 of which were from East Java; out of 19 district or city innovations, 3 were also from East Java. In 2018, East Java achieved 8 provincial places and 9 of 25 district and city places.

The research that underpinned the establishment of the innovation hubs found that the provincial government used several ways to share ideas on innovation, on its own or in cooperation with development partners. Some government units held regular monthly forums or annual conferences on different themes, including health and education, or on roles, such as a one-stop-shop health clinic management. This finding suggests that the innovation hub added to an already thriving innovation ecosystem.

\section{Conceptualizing the East Java Innovation Hub}

TRANSFORMASI supported by FutureGov and the Jawa Pos Institute of Pro-Autonomy led consultations in East Java in 2015. A consensus was reached, together with national and subnational stakeholders, on an agreement to establish an institution dedicated to innovation in public services with online and offline components based on "human-centered" design. These platforms would allow experimentation and testing of new ideas and ways of working, or solutions to service and policy problems. The core of this institution would be a network of government and external organizations that would promote innovation by providing access to prototypes, tools, templates, and skills. Figure 1 shows the main features of this knowledge-centered innovation hub. ${ }^{13}$
The Ministry of

State Apparatus

and Bureaucratic

Reform promotes

innovations to

improve frontline

services in health, education, civil

registry, and

environmental

protection.
Figure 1: Initial Concept of Innovation Hub

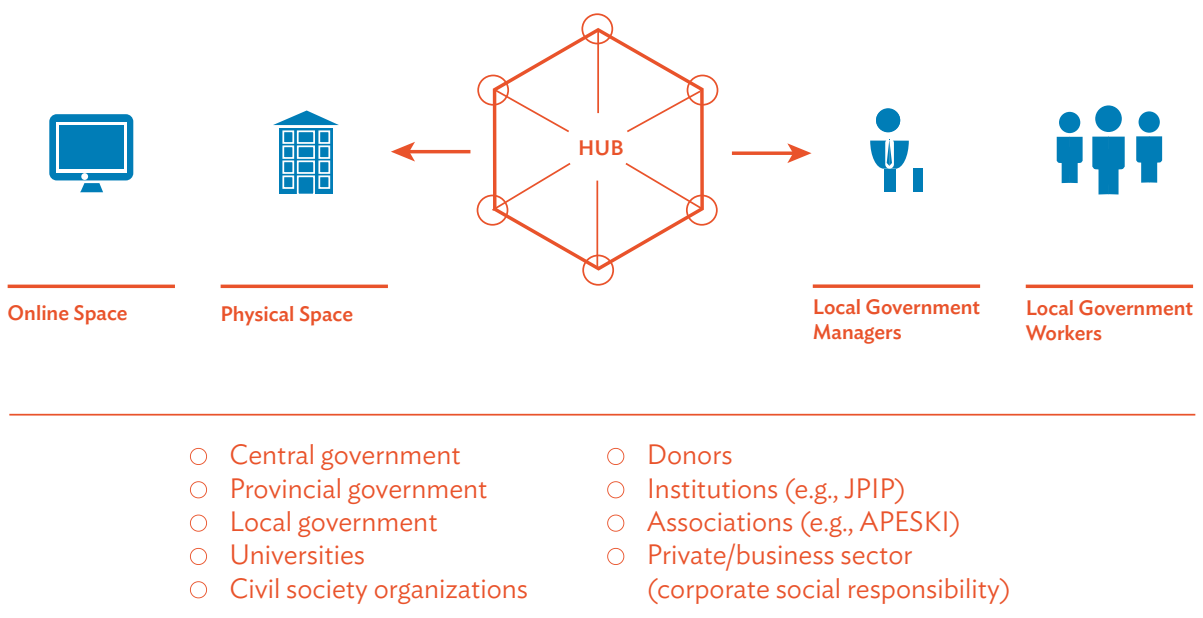

APESKI = Association of Indonesia Municipalities, JPIP = Jawa Pos Institute of Pro-Autonomy.

Source: FutureGov. 2015. Sharing Public Sector Innovation at the Subnational Level in East Java. Surabaya. 
In East Java, innovation hubs

provide local

governments and

other partners, such as civil society organizations, with opportunities for learning.
East Java is recognized nationally for fostering innovation. However, stakeholders have acknowledged a need for greater knowledge sharing. Attitudes toward hierarchy and legal constraints have also restricted progress. East Java adopted the innovation hub housed in the Organization Bureau ${ }^{14}$ to promote public service innovations in 38 district and city governments of the province.

The members of the innovation hub, established in 2015, are the East Java Provincial Government, Ministry of PANRB, Jawa Pos Institute of Pro-Autonomy, Brawijaya University, and the province level development partners: KINERJAUSAID, ${ }^{15}$ KINERJA-ADB,${ }^{16}$ KOMPAK-DFAT, and TRANSFORMASI. The provincial Organization Bureau is the secretariat for the network. The budget of the province is crucial in funding activities, but the members also make contributions.

Some of the activities supported by the innovation hub have gained formal status through the issuance of governor decrees, as in the case of the annual provincial public service innovation competition (KOVABLIK). In 2018, the provincial government budgeted the equivalent of $\$ 90,000$ for innovation hub activities.

\section{Innovation Hub Role and Stakeholder Perceptions- Study Findings}

In East Java, innovation hubs provide local governments and other partners, such as civil society organizations, with opportunities for learning. Public service innovations are shared through a website and offline activities, such as knowledge exchange forums, competitions, peer-to-peer learning, and innovation bootcamps.

In line with its original design, the Jawa Pos Institute for Pro-Autonomy has undertaken several activities since 2015 , repeating some annually (Table 1). The first activity implemented based on human-centered approach was a bootcamp to foster public service innovations.

The most visible elements of the innovation hub are the website inventory of innovations provided on the online platform and KOVABLIK. ${ }^{17}$ The website presents innovations from the province that are accessible to officials and the public. The innovation hub online platform is well-used by stakeholders, with several thousand visitors each month. From November 2015 to July 2019, the site

\section{Table 1: Main Activities of East Java Innovation Hub}

\begin{tabular}{|l|l|}
\hline Activity & Frequency \\
\hline Bootcamps to foster innovation & 4 rounds \\
\hline Innovations placed in the innovation hub website & 97 innovations \\
\hline Forum for exchanging knowledge and experiences & 6 rounds \\
\hline Forum for replication of innovation on province level and in regional clusters & 9 rounds \\
\hline Capacity development for innovation documentation & 12 events \\
\hline Innovation symposiums & 2 events \\
\hline Field visits to encourage inactive districts to engage in innovation & 9 times \\
\hline Annual Innovation Competition (KOVABLIK) & 3 rounds \\
\hline
\end{tabular}

Source: TRANSFORMASI. 2018. Role of the Innovation Hub in Nourishing Public Service Innovations. Draft Report.

14 The Organization Bureau is part of the provincial secretariat. It is responsible for the organizational setup of the provincial government and its efficient functioning.

15 USAID and Indonesia. 2015. Local Governance Service Improvement Program. Kinerja Core Final Report October 2010 to September 2015. Jakarta.

16 ADB. 2017. Unlocking Innovation for Development: Consolidating and Replicating Innovative Service Delivery Practices in Districts in Indonesia. Technical Assistance Consultant's Report. Manila (TA 9017-REG). https://www.adb.org/projects/ documents/ino49242-001-tacr.

17 Public Service Innovations Network East Java. http://jipp.jatimprov.go.id. 
received 71,794 visitors, $97 \%$ of whom were from Indonesia-41\% from East Java.

Proposals for the KOVABLIK competition must be submitted in a standardized format via the JIPP online platform. The proposals are then vetted by an independent jury. A technical guideline is available on how to document innovation and write innovation proposals. ${ }^{18}$ Winning innovations are added to the website. Interest in the competition has been high since its inception in 2016 and the number of innovations submitted has grown from 96 in 2016 to 191 in 2018.

The innovation hub is perceived largely as the online site by key informants. ${ }^{19}$ There is little awareness that activities, such as the innovation sharing forums, innovation-related training, study visits, and bootcamps (Table 1), are undertaken as a broad collaborative effort and are central to the innovation hub. Stakeholders are generally not aware that the onsite assistance or support provided throughout the innovation process is linked to the innovation hub.

The founding members of the innovation hub view the website as an important element in the "knowledge hub" aspect of the innovation hub. ${ }^{20}$ It is a tool to showcase and share public service innovations in East Java. Innovations are visualized on a provincial map and the provincial government uses this as a strategic tool to identify district and city governments that need support in identification and replication of innovations. This support then is carried out through an innovation network, combining government and nongovernment members.
At the same time, members are convinced that, for the hub's success, the offline component is of equal importance to the website. The entire set of actors, both offline and online platforms, comprise the innovation hub. While "soft support" was highly valued by innovators (e.g., WhatsApp groups established to facilitate learning or mentoring missions provided by the provincial and project team), this was not seen as a hub-related service but as an additional project or development partner support. The limited view of the innovation hub as the online component is therefore a concern and could be an obstacle to the proper functioning and development of the innovation hub and its further replication.

\section{Impact of East Java Innovation Hub on Innovation and Replication}

The introduction of the innovation hub in East Java has indeed spurred innovation. Contribution of innovations to the national competition (SINOVIK) have increased, compared to other provinces that do not have an innovation hub or are in the very early stages of its development. The dominance of the regional government in East Java in the top 99 SINOVIK from 2014 to 2018 is striking; for five consecutive years they have been the largest contributors to the top 99 national public service innovations (Table 2).

The emergence of the innovation hub in 2015 boosted submissions of proposals from East Java to the national competition in 2016 , when nearly

Table 2: Share of East Java Innovations in the Top 99 SINOVIK

\begin{tabular}{|l|c|c|c|c|c|}
\hline Year & 2014 & 2015 & 2016 & 2017 & 2018 \\
\hline No. of innovations & 16 & 18 & 30 & 17 & 19 \\
\hline \% of innovations & 16.2 & 18.2 & 30.3 & 17.2 & 19.2 \\
\hline
\end{tabular}

Sources: Data from the Ministry of State Apparatus and Bureaucratic Reform and the East Java Provincial Government.

\footnotetext{
18 Jaringan Inovasi Pelayanan Publik Jawa Timur. 2019. Materi II Bimtek Penyusunan Proposal Inovasi Pelayanan Publik. http:// jipp.jatimprov.go.id/?page=wawasan_detail\&id $=27$

19 There were 33 informants for innovation before 2018,17 in 2018,5 on replicators or replicators themselves, and 2 for facilitators of innovation.

20 TRANSFORMASI. 2015. Establishing a Public Service Innovations Network/Knowledge Hub. Jakarta.
}

In 2018, the

provincial

government

budgeted the equivalent of $\$ 90,000$ for innovation hub activities. 


In 2016, nearly
one-third
of winning
innovations in
the national
competition were
from district or
city governments
in East Java.

one-third of winning innovations were from district or city governments in the province. This has since moderated, as dominance of proposals from East Java led the central government to set quotas in 2017. ${ }^{21}$ Even so, East Java innovations remain above the level of 2014, before the idea of the innovation hub had been implemented. The achievement of $19.2 \%$ of awarded national innovations in 2018 is telling in view of the 35 provinces in Indonesia.

While the report does not trace the trajectory of all actors or potential innovations supported by the innovation hub, there is ample evidence of the catalytic function served in nurturing interest and promoting innovative ideas to the wider public. The case of the high-risk pregnancy seekers in Banyuwangi district described in Box 1 indicates how the innovation hub increased the visibility of a nascent innovation.

The members of the innovation hub recently found considerable variation in the intensity of innovation across East Java. Out of 38 districts and cities, 9 have no discernible innovations, 24 have some degree of innovation underway, and 5 are advanced in the level of innovation realized.

In line with its mandate, the innovation hub aims to equalize the generation of innovation across East Java. It is designing specific outreach activities for lagging district and city governments, helping them document existing innovations or develop new innovations. Table 3 shows the success of this strategy-participation in SINOVIK has spread to regional governments that were previously inactive.

\section{Box 1: High-Risk Pregnancy Seekers in Banyuwangi District}

Hadi Kusairi was prompted to act by the death of a neighbor and her child during childbirth in the yard adjacent to his house. As the head of Sempu Health Center, Hadi was determined to address the high mother and infant mortality rates in Banyuwangi District. Pak Hadi and several heads of health centers in East Java had participated in a bootcamp, an innovation training organized by the East Java innovation hub in collaboration with Brawijaya University Malang in 2015. After the training, he gathered local stakeholders in the three constituent villages of the district and, under the banner "Stop the Death of Mothers and Babies," sought ideas on how to support mothers during their pregnancy. They converged on the idea of enlisting the assistance of mobile vegetable sellers, majority of which were women, who made their daily rounds in distant neighborhoods. They intended to recruit 10 volunteers and train them to identify symptoms of high-risk pregnancies. The women were to be linked to the health center and the local hospital.

The system required funds so Hadi decided to bring his innovation to the Urun Ide, an innovation competition between regional government organizations held at the East Java innovation hub. Hadi explained, "Frankly, my motivation was the prize of $\$ 7,500$. Not for personal gain, but to finance the operation of this innovation." He eventually won the 2016 innovation hub competition. In addition to the prize, he benefited from technical assistance and mentoring of TRANSFORMASI partner Pulse Lab Jakarta, which was part of the award. Since 2016, the mortality rate in Sempu Health Center's constituency has been reduced to 0 for both maternal and infant deaths, from 16 pregnant women and 48 infants that had died since 2014.

The success on the ground and the preparation provided by the Innovation Hub allowed Hadi to turn his attention to SINOVIK (the national public service innovation competition) where his innovation won the title in 2016. The innovation hub linkage helped Hadi and his team to realize opportunities for innovation. Hadi had not expected the high-risk pregnancy seeker innovation to receive such broad attention. In November 2018, it was presented during the Open Government Partnership Regional Forum in Seoul, Republic of Korea.

Source: TRANSFORMASI. 2018. Role of the Innovation Hub in in Nourishing Public Service Innovations. Draft Report Qualitative Research.

21 In SINOVIK 2017, the Minister's Decree 19/2016 (Permenpan 19/2016) set a quota to restrict one province or local government from dominating in their class. The top 99 winners was set at 12 from ministries; 12 from provincial governments; and 36 from district and city governments in Java, Bali, and Sumatera; 20 from district and city governments from Kalimantan and Sulawesi; 7 from district and city governments from Maluku, Papua, Nusa Tenggara Timor, and Nusa Tenggara Barat; and 12 from state and local government-owned enterprises. With this regulation, East Java domination lessened considerably in SINOVIK 2017. 
Table 3: SINOVIK Submissions in East Java District and City Governments

\begin{tabular}{|c|c|c|c|c|c|c|c|c|}
\hline Regions & 2017 & 2018 & Regions & 2017 & 2018 & Regions & 2017 & 2018 \\
\hline \multicolumn{9}{|c|}{ Districts } \\
\hline Bangkalan & 0 & 1 & Banyuwangi & 10 & 11 & Blitar & 0 & 0 \\
\hline Bojonegoro & 5 & 4 & Bondowoso & 0 & 7 & Gresik & 6 & 25 \\
\hline Jember & 1 & 2 & Jombang & 5 & 2 & Kediri & 1 & 1 \\
\hline Lamongan & 0 & 5 & Lumajang & 2 & 2 & Madiun & 3 & 13 \\
\hline Magetan & 1 & 2 & Malang & 7 & 15 & Mojokerto & 5 & 12 \\
\hline Nganjuk & 1 & 2 & Ngawi & 4 & 46 & Pacitan & 6 & 16 \\
\hline Pamekasan & 1 & 5 & Pasuruan & 0 & 13 & Ponorogo & 1 & 0 \\
\hline Probolinggo & 2 & 3 & Sampang & 2 & 2 & Sidoarjo & 7 & 6 \\
\hline Situbondo & 3 & 8 & Sumenep & 2 & 3 & Trenggalek & 0 & 3 \\
\hline Tuban & 0 & 7 & Tulugagung & 2 & 15 & & & \\
\hline \multicolumn{9}{|c|}{ Cities } \\
\hline Batu & 7 & 0 & Blitar & 1 & 0 & Kediri & 0 & 3 \\
\hline Madiun & 3 & 42 & Malang & 2 & 7 & Mojokerto & 10 & 4 \\
\hline Pasuruan & 0 & 6 & Probolinggo & 0 & 5 & Surabaya & 5 & 9 \\
\hline
\end{tabular}

Sources: East Java Provincial Government, Organization Bureau.

Table 3 also shows that cities became more innovative, with a $271 \%$ increase from 28 in 2017 to 76 in 2018 . On average, innovation submissions stood at 8.44 per city and 7.96 per district in 2018 . Submissions of districts increased 300\% from 77 in 2017 to 231 in 2018. The spatial pattern of growth suggests that the innovation hub and other actors have played a role in increasing the rate of innovation and convergence across district and city governments.

The work of the innovation hub has generally sparked interest in innovation. Several districts and cities in East Java are now holding their own public service innovation competitions. These serve to prepare and screen innovations for submission to provincial-level competitions.

The study followed the trajectory of some innovations to gauge their success and how they were replicated elsewhere. Figure 2 depicts several ways in which innovations gain traction:

- Innovation can spark interest to further improve public services, cutting across fields of governance.
The work of the innovation hub has generally sparked interest in innovation. 


\section{Where the local}

context demands

some alterations

or adaptations,

\section{replication is}

\section{undertaken but may}

differ substantially

from the original

innovation.
- Where the problems faced by potential innovators are similar to those that led to the original innovation, the potential innovator can recreate the idea in another regional government. This is replication in its pure form.

- Where the local context demands some alterations or adaptations, replication is undertaken but may differ substantially from the original innovation. The process of adoption with adaptations can be seen as involving some innovation to suit the local context. This follows the guidance of the central government regulations (Permenpan 30/2014), encouraging full or partial replication. ${ }^{22}$

- Replication, with high fidelity or some adaptation, could also happen in the original context if the innovation was initially limited to a subset of the potential institutions that could take up the model offered. This is then replication in the form of institutionalization or scaling up.

To demonstrate the above possibilities, the study examined the high-risk pregnancy seekers innovation (Box 1), noting its institutionalization and how it scaled up within Banyuwangi District. Once the success became evident, the district moved to institutionalize the support needed to maintain it. The high-risk pregnancy seekers receive operational health assistance from the health block transfer grant of \$10 per month. Village facilitators in the program obtain financial support from the village fund allocation. In 2018, 44 other health centers across Banyuwangi had taken up the model and are now empowering female vegetable sellers as high-risk pregnancy seekers. Financial support is provided by the health block transfer grant and the village fund. Replication across districts is also evident, with more than 10 similar innovations (with some level of modification) noted.

In another case of replication, the rotary sanitary landfill system in Talangagung of Malang District became a model of integrated waste management for other districts (Box 2). The early innovation and replication in this case shows that there were already robust mechanisms to support the process of innovation and replication in place prior to the innovation hub's establishment.

It is not unusual for innovations from service delivery to be replicated within district and city governments-across other service units-and in other district and city governments (Figure 2). Box 3 provides an example of this institutionalization and external replication in Malang District. The external replication in this case was partial.

Figure 2: Pathways to Large Impact of Innovations

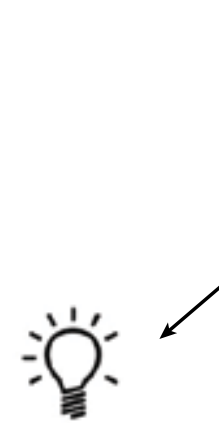

Innovation in region $Y$ (unrelated to original idea; drive to innovate was sparked)

Source: Asian Development Bank.
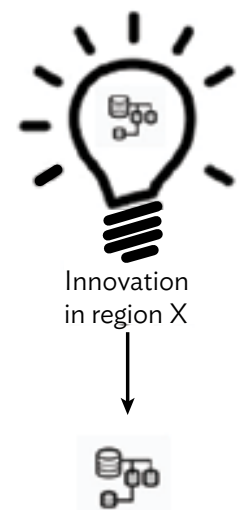

The original innovation in region $X$ is replicated in region $Z$ (full replication)
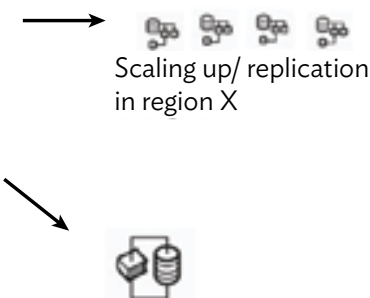

The original innovation in region $\mathrm{X}$ is replicated in part in region $\mathrm{W}$

22 Peraturan Menteri Pendayagunaan Negara dan Reformasi Birokrasi Nomor 30 Tahun 2014 Tentang Pedoman Inovasi Pelayanan Umum. 


\section{Box 2: Replication of the Talangagung Integrated Waste Management in Malang District}

The waste management site (TPA) in Talangagung subdistrict manages waste by stacking garbage into a shallow hole, compacting the waste, and then closing the hole with soil (mixing organic and non-organic waste).

Degradation of unprocessed waste usually produces leachate, which can pollute the environment. The leachate is therefore channeled to a wastewater treatment plant to be neutralized before being returned to the environment. This technology has been replicated in many regions (e.g., TPA Benowo in Surabaya since October 2012; TPA Manado, North Sulawesi since December 2013; Trans LIK TPA Pasir Panjang Village, Kotawaringin Barat Regency, Central Kalimantan since 2015; and TPA Randegan of Mojokerto in 2016).

The latest replication is the construction of a sanitary landfill system in Sidoarjo Regency which is under construction.

Source: TRANSFORMASI. 2018. Role of the Innovation Hub in in Nourishing Public Service Innovations. Draft Report Qualitative Research.

\section{Box 3: Contra War in Malang District (Contraceptives Drive)}

CONTRAceptives for Woman At Risk (Contra War) aims to reduce maternal and infant mortality rates (MMR/IMR). Initiated by the Malang Regency Population and Family Planning Control Board, it promotes appropriate contraceptive use for women of childbearing age who are at high risk of infectious diseases, non communicable diseases, congenital diseases, and complications due to previous pregnancies.

Women of childbearing age who are at high risk comprise about $60 \%$ of MMR/IMR. Contra War is innovative as it records them by name, address, and case. The district response relies on realtime reporting of cases with appropriate and immediate offers of contraceptives. Contra War has been applied across all health centers in Malang District since 2015. It has reduced MMR/ IMR by around $50 \%$. In 2018, Contra War was selected as one of the top 40 innovations in the national SINOVIK competition.

This innovation also inspired partial replication in North Luwu District of South Sulawesi in 2017. The component of Contra War that was replicated focused on targeting a high-risk group, particularly among pregnant women. The innovation on hypnotherapy-based antenatal care treatment was carried out in hospitals and health centers. Pregnant women are conditioned to undergo labor and address pain through relaxation methods and emotional freedom techniques.

The results of the psychological preparation enable mothers to focus on what is important at the time, such as the pain expected during labor. When the expectant mothers attend the classes, midwives and the health center's medical team are also present to ensure that they are under regular observation. MMR in North Luwu District also fell significantly from 11 deaths in 2016 to 5 deaths in 2017 and 2 deaths in 2018 (unattended by midwives).

Source: TRANSFORMASI. 2018. Role of the Innovation Hub in in Nourishing Public Service Innovations. Draft Report Qualitative Research. 
A concerted effort

by all supporting actors is required to balance the push for innovation with replication.

\section{Conclusions and Recommendations}

The study provides evidence that the innovation hub in East Java has been instrumental in spreading the spirit of innovation and intensifying a culture of innovation across regional governments. It also benefited from the existing ecosystem of support in the province that consequently continues to grow. The innovation hub enabled East Java to become a dominant province with its district and city innovations being recognized and awarded at the national level.

This success, however, has not translated into widespread replication of recognized innovations. The innovation hub is perceived as an online platform for original innovations. In fact, it provides online and offline support services for both innovation and replication.

For a larger and more systemic impact, the Ministry of PANRB and its partners should support the expansion of provincial innovation hubs, emphasize their holistic approach, and develop policies and incentives to encourage replication. The study further concludes:

Innovation is gaining momentum and responds to support. The findings suggest that the innovation process has gained traction in East Java-innovation is accelerating. With adequate support, most district and city governments can generate service innovations within 1-2 years. Establishing and developing provincial innovation hubs to influence the rate of innovation can be accomplished within 3-5 years.

The innovation hub has a positive influence in promoting innovation and replication in district and city governments. Its activities drive innovation and replication, particularly in terms of visibility; facilitating interaction between stakeholders (e.g., innovators and replicators); and focusing attention on lagging district and city governments.

\section{Replication does happen, but not enough. Even}

when a provincial innovation hub is present, innovations diffuse slowly by replication. In part, the pace reflects a perception bias. There are similarities in innovations identified, suggesting that they are better viewed as replication "with adaptations." Replication is happening, but it is not readily acknowledged. Replication is negatively viewed and rigidly regarded as the exact repetition of the original innovation, rather than a continuum of adoption and adaptation. Unfortunately, there is a wide perception that replication is not as important as innovation and unworthy of the same recognition or reward. The search for originality can be counterproductive if overall improvement in public services is the ultimate goal. Most improvements are incremental; innovations that have been recognized in the KOVABLIK and autonomy awards are largely of this kind. They make an important difference in service reach and quality in the local level (and, if scaled up, even in the regional and national levels).

Innovation hubs should build on existing efforts. The study confirms previous findings on the key role of leadership in establishing an enabling environment for second-level leaders (heads of regional government agencies and service implementation units). They are involved in a range of associations and partnerships that support innovation. The innovation hub provides a platform and suite of services that accelerate the work of this innovation ecosystem.

The innovation hub is restricted by perceptions about its scope and institutional setup. This makes a holistic approach to innovation and replication (including online and offline elements) more difficult to achieve. Even provincial government staff see the innovation hub largely as an online resource and competition. But most of the efforts and resources need to be directed to offline activities that support innovation and replication through training, meetings, and technical guidance.

\section{Existing incentives have spurred innovation} but largely failed to replicate innovations on a large scale. While provincial and national support has been crucial to the growth of innovation to date, the process has been largely voluntary. Incentives (prizes and recognition) have encouraged participation and outreach to lagging regions has been helpful. However, at the provincial and national levels, efforts to institutionalize innovations are limited (e.g., to make them mandatory and support them as elements of public service delivery). Paradoxically, the substantial discretion afforded to district and city governments by decentralization reforms has made it harder for higher-level government to impose a coherent frame for service performance tracking and improvement. Innovation hubs and other innovation efforts rely on local leadership, leaving innovations vulnerable to short-term political 
interests. There may be room for a better balance between bottom-up innovation and higher-level guidance in the adoption of innovation if existing regulations are fully applied and refinements in intergovernmental relations are made. Such a systemic approach could contribute significantly to the achievement of the SDGs if multiplied within and across district and city governments.

Pressure to innovate and, in particular, to replicate must ultimately come from an engaged civil society demanding better public services at the local level. The study did not fully explore this dimension, but it is evident that social accountability can play a larger role in promoting public services in Indonesia. The innovation hub has enlisted the participation of citizens in its work. However, it needs to intensively support civil society engagement and signal to government agencies the need and value of public service improvement.

The following are recommendations:

National support for the innovation hub concept and its adaptation should be maintained.

There is evidence that innovation (and to a lesser extent, replication) in the regions will increase where an innovation hub is established. National and provincial governments should further institutionalize the generation of innovations. This could be achieved, for example, by instructing district and city governments to mainstream proven innovations in policy and planning processes. National and provincial governments should integrate proven innovations into their own policies, programs, and technical support to ensure replication on a broad scale.
The concept of the innovation hub needs to be promoted as a holistic combination of online and offline programming.

\section{A concerted effort by all supporting actors is} required to balance the push for innovation with replication and institute an approach that provides incentives to new innovations as well as replication of specific innovations beyond their original site.

The national government and stakeholders should consider shifting from "replication" to other terms that are more positive, such as "adoption" or "transfer of innovation," and explicitly stating that replication is encouraged and respected by the government. A looser interpretation of replication would also facilitate replication, possibly involving the basic idea, technique, or managerial approach, with adaptations as necessary to make the initiative relevant to the new context.

Through innovation hubs and other platforms, national and provincial governments need to identify which innovations are most important to achieving public service goals associated with the SDGs. Coding of innovations in the innovation hub online inventory according to the specific relevance to the SDGs could align innovations to these national imperatives.

This governance brief was peer-reviewed by Azusa Sato, health specialist, $A D B$, and Rainer Rohdewohld, senior governance consultant. 


\section{Further Reading}

G. Ferrazzi and R. Rohdewohld. 2017. Emerging Practices in Intergovernmental Functional

Assignment. London: Routledge.

Government of New South Wales, Australia, Public Service Commission. 2013. Creating an Innovative Public Sector. Discussion Paper. Sydney.

K. Star and G. Coussa. 2018. Enough Innovation Already! Stanford Social Innovation Review. April.

Organisation for Economic Co-Operation and Development. 2017. Core Skills for Public Sector Innovation. Paris.

Pulse Lab Jakarta. 2015. Tips on Public Service Design for the Public Sector. 17 November. https:// medium.com/pulse-lab-jakarta/tips-on-servicedesign-on-public-sector-d3760ccfd00c\#.\%20 pg7nbybst.
TRANSFORMASI. 2016. 8 Steps to Transfer Innovations for Improved Public Service Delivery. Jakarta.

\author{
- - - 2018. Establishing a Public Service \\ Innovations Network / Knowledge Hub. A step by \\ step Implementation Guide. Jakarta. \\ -_- 2018. Innovation Documentations. \\ Reducing Maternal and Infant Mortality via High \\ Risk Pregnancy Hunters. Jakarta. \\ -_- 2018. Innovation Documentations. My \\ Family Card Update. Updating Population Data in \\ Gresik District, East Java. Jakarta.
}

